\title{
Local climate change reporting in coastal cities: Selsey (UK), Santos (Brazil) and Broward County (USA)
}

\author{
Cobertura mediática local del cambio climático en ciudades costeras: \\ Selsey (Reino Unido), Santos (Brasil) y Broward County (EEUU)
}

\section{Eduardo Prado Gutiérrez}

Universidade Estadual de Campinas | Cidade Universitária Zeferino Vaz, 13083-970, Campinas | Brasil | https://orcid.org/0000-0001-7279-7176 | eduardopgutierrez@hotmail.com

Dates | Received: 23/09/2021 | Accepted: 14/12/2021

\begin{abstract}
Climate change media coverage has been criticized for giving voice to denialist sources and for its detachment from local and individual experiences, emphasizing catastrophic and global impacts. This article seeks to understand the potential connection between regional media and local climate change meanings through analysis of the journalistic output in regional newspapers in three vulnerable coastal cities that have presented developments regarding local climate governance: Santos (Brazil), Selsey (UK) and Broward County (USA). The vehicles analyzed in each of the cities are A Tribuna de Santos, The Chichester Observer and The Sun Sentinel, respectively. The method used is quantitative content analysis, focusing on the appearance of sources and recurring local issues and symbols on the climate change coverage of these regional vehicles. As a result, there are interesting differences of sources and issues between regions, with beaches and shoreline neighborhoods condensing the attention over climate impacts in Santos and Broward; and the dangers of real estate development in lowlying land and natural reserves occupying the
\end{abstract}

\section{Resumen}

La cobertura del cambio climático ha sido criticada por dar voz a fuentes negacionistas y su alejamiento de las experiencias locales e individuales, enfatizando los impactos catastróficos y globales. Este artículo busca comprender la potencial conexión entre los medios locales y regionales y los significados locales del cambio climático, a través de la análisis de cobertura mediática de los periódicos regionales de tres ciudades costeras que han presentado avances en relación con la gobernanza climática local: Santos (Brasil), Selsey (UK) y Broward County (USA). Los periódicos analizados en cada ciudad son 'A Tribuna de Santos', 'The Chichester Observer' y 'The Sun Sentinel', respectivamente. Metodológicamente, se opta por el análisis cuantitativo de contenido, centrándose en las fuentes, símbolos y cuestiones locales frecuentes en la cobertura del cambio climático en estos diarios de difusión regional. Como resultados, vemos interesantes diferencias de fuentes y temas entre regiones, con playas y barrios de playa condensando la atención de impactos climáticos en Santos y Broward; mientras que en Selsey ganan atención los peligros del 
center of attention in Selsey. Among the three locations, only Broward presented a significant degree of climate denialist sources.

Keywords: climate change, communication, local press, science and society. desarrollo inmobiliario en áreas bajas y de reserva natural. Entre las tres localidades, apenas Broward presentó un grado significativo de fuentes que niegan el cambio climático.

Keywords: cambio climático, comunicación, prensa local, ciencia y sociedad.

\section{INTRODUCTION}

\subsection{Denialism and the scales of climate change}

Most of the population learns about climate change and scientific subjects through the media, making it a key instance for the perception of climate risks (Hansen, 2010; Pidgeon et al., 2003). However, reporting on the issue has been criticized because of the attention given to denialist sources in the last decades, especially in English-speaking countries (Boykoff \& Boykoff, 2007; Brulle, 2013). Journalistic norms of balance have been exploited by the climate counter-movement (CCM) and its think-tank-based experts, making uncertainty over climate science a major framing option which has also spread to European countries (Nisbet, 2010; Brulle, 2013; Almiron et al., 2020).

Moreover, some more subtle aspects of the global coverage have been questioned, such as its detachment from local subjects and its emphasis on the irreversibility and gravity of the phenomenon (Nisbet, 2010; Braasch, 2013; O'Neill \& Nicholson-Cole, 2009). The concentration of references at the international level strengthens the perception of climate change as an abstract entity, adding to the problematic stated by Jasanoff (2010, pp. 234-243), who defines it as a scientific object that spills out of the limits of lived experience, in a divorce between fact-finding and meaning-making. In that sense, the circulation of the topic through the media is frequently separated from local meanings and dominated by international scientific and governmental elites, adding to skepticism in the audience and 'hyperopia' regarding climate impacts, which are perceived as distant in space and time (Lorenzoni et al., 2007; Boykoff, 2011; Leiserowitz et al., 2020).

In this scenario, regional media can play an important role producing content about spatially diverse climate impacts, instead of echoing the homogenized reporting of international wire services. It can provide information about local problems salient to the audience, linking "global and local subjectivities" (Jasanoff, 2010, p. 247). Furthermore, the operation of regional news has been linked to reduction in political polarization in an array of cities in the United States, providing a forum where citizens can identify while locals, different from the national media, where citizens usually filter the information through ideological and partisan lens (Mason, 2016; Darr et al., 2018).

Therefore, this article proposes to enrich the literature on regional climate reporting by studying local newspapers based in vulnerable coastal cities. The cases here selected are Santos (Brazil), Selsey (UK) and Broward County (USA), due to their particular contexts, permeated by scientific and institutional developments on the subject of climate change. The 
media analyzed for each case are the print newspapers A Tribuna de Santos, The Sun Sentinel and the digital version of The Chichester Observer.

The initial motivation for the choice of the cities was their selection for study under the METROPOLE Project, an international scientific initiative approved in the scope of the Belmont Forum and financed by research agencies in Brazil, in the UK and in the USA (Marengo et al., 2017). The project has projected climate scenarios and economic impacts for each location, rendering the following results: in a low sea-level rise scenario, cumulative damage from climate change between 2010 and 2100 will reach 242 million dollars in Santos, between 2010 and 2060 would amount to 3.35 billion dollars in Broward County, while in Selsey the cost of a one-time event ${ }^{1}$ with 100-year recurrence would cause 42.3 million dollars in damage after 2085 (Marengo et al., 2017). The study strengthens an economic discussion in the cities, presenting benefit-cost ratios of respectively 24 and 22 times for climate adaptation in Santos and Broward.

That said, for each of the cases this article seeks to understand the circulation of the climate change issue in local newspapers to the light of political, institutional, and scientific developments in the locations, analyzing interactions between global and local problematics, including the influence of local meanings and North and South discussions. The different contexts of the localities, permeated by specific environmental conditions and political dynamics, make for an interesting comparative analysis.

The general objective is to characterize local coverage through content analysis, in the process accomplishing the following specific objectives: to identify the differences in the use of sources, the mobilizing issues and symbols, and the occurrence of knowledge or policy-related climate denialism, which respectively consist of denying scientific soundness of climate change science (climate denialists) and obstructing climate action and policies (climate action obstructionists) (Almiron et al., 2020). The main hypotheses here considered are (1) the regional climate change discussion is condensed around public goods and local symbols, and (2) denialist stances are mainly connected to conservative discourses and the private sector.

The article is structured in order to present a theoretical review and problem statement in the following section, also detailing the methodological options. In this perspective, the cultural theory of risk (Douglas \& Wildavsky, 1983) and the social amplification of risk framework (Pidgeon et al., 2003) are central, conjugated to a content analysis methodology (Bardin, 1977) that allows us to understand the predominant issues, sources and symbols in the coverage. In Section 3, this article presents the results of the case studies, and finally, in Section 4, the results are discussed, with concluding remarks.

\section{THEORETICAL REVIEW AND PROBLEM STATEMENT}

\subsection{Risk, worldviews, denial, and the local scale}

Problematic aspects of climate change media coverage such as the presence of denialist sources and the difficulty to connect climate science to local meanings can also be seen as a

${ }^{1}$ Results not available for cumulative damages. 
symptom of a conflict that has profound roots in modern society. The media reflects dominant modern ideologies centered around positivism, constituted by empiricist notions and a dichotomy between civilization and nature (Hannigan, 2006).

Such concepts can be clearly observed in the operating criteria of news vehicles, which function by connecting dispersed audiences to centers of social power (Hall, 1973), privileging the coverage of economic and institutional agendas (Boykoff, 2011). The American and English media have been permeated by climate change denial and the Brazilian media has dismissed the entire environmental debate for decades, considering it an alarmist and anti-modern rhetoric, opposed to the economic development consensus that was held in the centers of political power (Andrade, 1994; Boykoff \& Boykoff, 2007; Ferreira \& Tavolaro, 2008).

These examples illustrate the challenge in which modern civilization finds itself in relation to environmental risks. The global environmental changes emerging from the ever-accelerating production of economic goods upend the major political narratives of the twentieth century, centered around notions of productivism and technical progress (Chakrabarty, 2009; Jasanoff, 2010). The environment, long seen as a source of stability, becomes a source of doubt, staining the modern hubris and demanding a rearrangement of our relations with nature (Douglas \& Wildavsky, 1983, p. 10).

Climate change, as a global risk, evidences the connection between environmental degradation and fossil fuel use, the energetic base upon which modern civilization has been powered (Chakrabarty, 2009). Furthermore, it scrambles traditional concepts of the Nation State, with climate science upsetting prevailing arrangements of co-production between scientific knowledge and national power, ripping the grain of conventional social narratives (Jasanoff, 2010). In that context, a confrontation takes place between this scientifically defined risk and dominant ideologies and economic systems (McCright \& Dunlap, 2010).

Being in a position that upsets power arrangements, the climate scientific consensus is attacked by economic and ideological parties. Literature in the field of climate change denialism in the United States has found that skeptical scientists and politicians are well funded through oil, auto and extractive industries, associated to conservative foundations and think tanks, such as the Heritage Foundation and the Heartland Institute (Brulle, 2013). Also, the demographic groups most convinced by the CCM rhetoric are usually white males associated to conservative political lines (Shwom et al., 2015).

Such division has prompted sociologists Dunlap and McCright (2000) to suggest the 'antireflexivity' thesis, in which skepticism is a mechanism adopted by privileged groups to avoid the constitution of climate change as an urgent social problem. That is because, in their perception, prioritization of climate change mitigation could require substantive changes to the social order based on the neoliberal consensus, which would be an undesired development in these groups' perception.

Such a cultural problematic around environmental risks has been discussed as early as 1983 by anthropologists Mary Douglas and Aaron Wildavsky, who have theorized that different social groups hold different assumptions about the resiliency of the environment, the most urgent 
social priorities, and, essentially, the way society works or ought to work. Therefore, the decisions about which risks and dangers should be minimized and the level in which they have to be minimized are inherently political, involving conceptions of a desired social order and convictions on how human beings can live well together.

In that sense, a desired climate and the measures to safeguard it interact with other risks and social problems, taking place in public arenas marked by conflict that cannot be entirely solved by science. It is with that in mind that Douglas and Wildavsky (1983) concluded that environmental risks can lead not to the unification of society, but to further divisiveness, given the long-held convictions about the stability and subordination of nature

Works in the field of cultural cognition have confirmed the divides theorized by Douglas and Wildavsky, identifying a difference in perceptions of climate change between groups with differing worldviews (Akerlof et al., 2016). The divisions run along the perceived degrees of Hierarchy and Individualism necessary to the functioning of the social order, as opposed to values of egalitarianism and communitarianism (Figure 1).

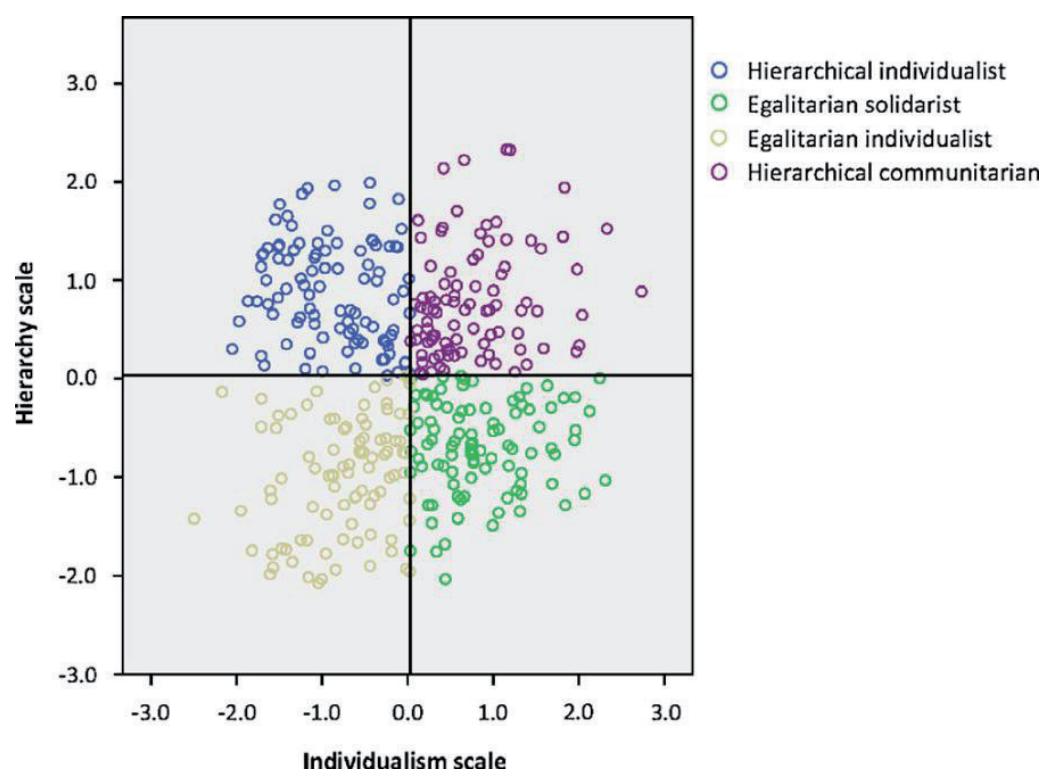

Figure 1. Operationaliation of the typology defined by Douglas and Wildavsky (1983), in order to classify interviewees according to their worldviews

Source: Akerlof et al. (2016).

Hierarchical individualistic worldviews usually lead to opposition to regulations on commerce and industry, perceived as hostile to principles of freedom of initiative. In that sense, individuals with that worldview are also the most predisposed in perceiving climate change with skepticism (Akerlof et al., 2016).

In that context of polarization, Kahan (2010) states that reaching across divides is a difficult communicative task, since different social groups usually perceive credibility in different ways. 
The author suggests that the dynamics of identification are at the source of polarized perceptions, and risk messages are hardly efficient when they contain strong political cues and cultural identities opposite to the ones the individual values. Brulle et al. (2012) have also found that political cues are the main driver of climate change convictions in the United States, suggesting that changes in perception depend on a broader political strategy that leads to consensus across the elites.

Nevertheless, local communication of risk can provide an interesting locus in which divides can be bridged. Workshops about climate impacts in coastal cities have provided interesting results, as the perceptions of climate risk by individuals located within the hierarchical/individualist quarter were the most improved (Akerlof et al., 2016). As is the case with the local media, such experiments can foster identification between citizens as members of a local community, paving the way for improvement of the perception of increasing risks to their regions. That, of course, does not replace the need forconsensus reaching between elites, but certainly is an interesting way forward in polarized contexts.

With that in mind, this article aims to grasp the nature of newspaper coverage in moments of political effervescence and social risk amplification ${ }^{2}$ (Pidgeon et al., 2003) in each location proposed. Here conceived as a multidimensional message, climate risk can be amplified or minimized during its social trajectory, a process determined by factors such as social stigmatization, trust between social groups, perception of institutions as competent or not, and also its heuristics (Pidgeon et al., 2003).

In that sense, valued public goods can symbolize and condense local problems regarding the climate. Ecosystems such as beaches and coral reefs allow for easy cognitive connections between climate change and environmental degradation, working as symbols where local and global subjectivities are projected and interact (Jasanoff, 2010). They can give rise to different interpretations based on historical contingencies, fostering meanings related to preservation, care and systems thinking, or, on the other hand, meanings in which they are conceived as obstacles to development (Ferreira \& Tavolaro, 2008; Batty et al., 2008).

\subsection{Methodology}

Written newspapers were chosen for analysis, given the larger issue-space dedicated to environmental matters when compared with TV news (Boykoff, 2011). The vehicles chosen for analysis were the reference newspapers for each location: $A$ Tribuna de Santos (Santos), The Sun Sentinel (Broward County), and The Chichester Observer (Selsey). The first two are daily newspapers that provide digital and print editions, with no content difference between them. The Chichester Observer, in contrast, has a weekly frequency ${ }^{3}$ and does not provide copies of its print edition online, only a digital archive and indexed search for the news stories that are constantly uploaded to its website.

\footnotetext{
${ }^{2}$ When the social perception of risk ripples through different layers of the community, beyond the groups directly affected by the hazards.

${ }^{3}$ Local newspapers in the UK are predominantly weekly and adopt the compact format, also common among national newspapers. More information: <https://www.britishpapers.co.uk/glossary/>. Access on: $03 / 12 / 2021$.
} 
Exhaustive searches have been conducted for each vehicle, with the respective time periods and resulting samples specified in Table 1. During the process, the scope of the texts was analyzed and the ones with a regional scope and more than a passing mention ${ }^{4}$ of climate change were registered as units of analysis, leading to the results displayed in Table 1 . Texts with a short mention or national/international scope were not registered.

Table 1

Newspapers, search periods and resulting samples

\begin{tabular}{|c|c|c|c|}
\hline & Santos & Broward County & Selsey \\
\hline Newspaper & $\begin{array}{c}\text { A Tribuna de Santos } \\
\text { (print edition) }\end{array}$ & $\begin{array}{c}\text { The Sun Sentinel (print } \\
\text { edition) }\end{array}$ & $\begin{array}{c}\text { The Chichester Observer } \\
\text { (online news) }\end{array}$ \\
\hline Time Period & $09 / 2015-04 / 2018$ & $05 / 2014-01 / 2016$ & $10 / 2015-07 / 2021$ \\
\hline Search Method & $\begin{array}{l}\text { Physical archive } \\
\text { (Database from } \\
\text { Gutiérrez (2021)) }\end{array}$ & Digital archive & $\begin{array}{l}\text { Automated search } \\
\text { through the website. }\end{array}$ \\
\hline Keywords & $\begin{array}{l}\text { 'aquecimento global', } \\
\text { 'mudança do clima', or } \\
\text { 'mudança climática' }\end{array}$ & $\begin{array}{l}\text { 'global warming' or } \\
\text { 'climate change' }\end{array}$ & $\begin{array}{l}\text { 'global warming' or } \\
\text { 'climate change' }\end{array}$ \\
\hline Texts analyzed & $\begin{array}{c}\text { News and opinion texts } \\
\text { (excluding letters to the } \\
\text { editor }{ }^{6} \text { ) }\end{array}$ & News and opinion texts & News and opinion texts \\
\hline Units of analysis & 71 & 145 & 122 \\
\hline
\end{tabular}

Source: own elaboration.

The sample was submitted to a quantitative content analysis (Bardin, 1977) in order to determine the dominant local actors and issues in the coverage. The three variables analyzed are: sources, main local issues, and parts subject to risk in the coverage.

Understanding the media through a constructionist approach (Gamson \& Modigliani, 1989), the identification of sources in the coverage is a major aspect for the analysis, as it allows us to identify actors who are shaping the public debate. On issues of environmental risk, a broad array of actors can be identified. Analyzing local coverage about oil permits off the coast of Spain, Mercado-Sáez, Sahuquillo-Verdet and Chávez (2019) propose Actor/Source categories such as 'Politicians', 'Experts', 'Social Movements' and 'Industry'. The first two are largely mirrored by the types of 'Governmental/Political' and 'Scientific' here adopted (Table 2), while to account for other types, this article adopts the broader categories of 'Private' and 'Civil Society', that allow for enhanced comparability among locations and mirrors categories adopted in climate governance studies (Broto \& Bulkeley, 2013). Occurrence of climate denialism (Almiron et al., 2020) among the sources was also registered for further analysis.

\footnotetext{
${ }^{4}$ When the issue appears with Medium or Central density in the article (ANDI, 2010).

${ }^{5}$ Through web-crawling software Octoparse: <https://www.octoparse.com/>. Access on: 03/2021.

${ }^{6}$ Due to the unavailability of this type of text both in the digital archive and in the database from Gutiérrez (2021), it was not included in the analysis. Due to the reduced issue-space dedicated to this type of text, it is unlikely to significantly affect the results.
} 
Table 2

Typology for source classification

\begin{tabular}{|c|c|c|c|}
\hline \multicolumn{3}{|c|}{ Sources } \\
\hline Scientific & Governmental/Political & Private Sector & Civil Society \\
\hline
\end{tabular}

Source: adapted from Gutiérrez (2021).

The next variable regards main local issues that mobilize climate change coverage. As a qualitative variable, the methodological steps are the inductive elaboration of an inventory of categories after the reading of the texts and the deductive classification of the units of analysis according to the dominant issue identified (Bardin, 1977; Van Gorp, 2010). Table 3 lists and explains the categories obtained, which make visible regular issues motivating the texts.

Table 3

Main local issues motivating climate change (CC) coverage in each location

\begin{tabular}{|c|c|c|}
\hline & Main local issues & Explanations \\
\hline \multirow{9}{*}{$\begin{array}{l}\text { Broward } \\
\text { County }\end{array}$} & Elections & Appearance of CC in electoral debate \\
\hline & Denialism & Declarations of authorities focusing validity of CC science \\
\hline & $\begin{array}{l}\text { King tides, hurricanes and } \\
\text { flooding }\end{array}$ & Natural events motivating CC discussion \\
\hline & Coral reefs & Perceived effects of CC on coral reefs \\
\hline & Development & Judicial/popular questioning of controversial projects \\
\hline & Scientific projections & Publishing of CC studies \\
\hline & Activism & Activist demonstrations \\
\hline & Action plans & $\begin{array}{l}\text { Publishing and implementation of climate-specific } \\
\text { legislation. }\end{array}$ \\
\hline & $\begin{array}{l}\text { National assessments and } \\
\text { legislation }\end{array}$ & Perceived local effects of national legislation \\
\hline \multirow{5}{*}{ Santos } & \multicolumn{2}{|l|}{ Storm surges and erosion ${ }^{7}$} \\
\hline & $\begin{array}{l}\text { Responsibilities and } \\
\text { impacts on the port }\end{array}$ & $\begin{array}{l}\text { Judicial/popular questioning of the Port or perceived } \\
\text { impacts. }\end{array}$ \\
\hline & \multicolumn{2}{|l|}{ Scientific projections } \\
\hline & \multicolumn{2}{|l|}{ Activism } \\
\hline & \multicolumn{2}{|l|}{ Action plans } \\
\hline \multirow{5}{*}{ Selsey } & Climate emergency & $\begin{array}{l}\text { Institutional discussion and protests over declaration of a } \\
\text { climate emergency. }\end{array}$ \\
\hline & \multicolumn{2}{|l|}{ Development } \\
\hline & \multicolumn{2}{|l|}{ Action plans } \\
\hline & \multicolumn{2}{|l|}{ Elections } \\
\hline & Divestment & $\begin{array}{l}\text { Popular/institutional questioning of public investment in } \\
\text { GHG emitting businesses. }\end{array}$ \\
\hline
\end{tabular}

Source: own elaboration.

Finally, 'Parts Subject to Risk' (Table 4) identifies local entities recurrently mentioned as vulnerable to climate change in the units of analysis, evidencing social foci of concern and local symbols that condense perception of risk.

\footnotetext{
${ }^{7}$ Themes in italics have already been explained. For example, 'Storm Surges and Erosion' shares the explanation for 'King Tides, Hurricanes and Flooding'.
} 
Table 4

Parts Subject to Risk identified in the coverage for each location

\begin{tabular}{|c|l|}
\hline \multirow{4}{*}{ Broward County } & \multicolumn{1}{|c|}{ Parts Subject to Risk } \\
\hline & Coasts, Beaches \\
\cline { 2 - 2 } & Neighborhoods, Real Estate at Risk \\
\cline { 2 - 2 } & Coral Reefs \\
\cline { 2 - 2 } & Roads \\
\cline { 2 - 2 } & Everglades \\
\hline \multirow{4}{*}{ Santos } & Beaches, Ponta da Praia neighborhood \\
\cline { 2 - 2 } & Port \\
\cline { 2 - 2 } & Northwest Zone neighborhood \\
\hline \multirow{3}{*}{ Selsey } & Parks (South Downs, Arun Valley), Chichester Harbour \\
\hline & Low-lying neighborhoods \\
\cline { 2 - 2 } & Coasts \\
\hline
\end{tabular}

Source: own elaboration.

\section{RESULTS}

\subsection{Santos (Brazil)}

Santos is home to the most important Port of Latin America and is the biggest coastal city of the State of São Paulo, with administrative autonomy granted by the Brazilian Constitution. A highly unequal city, it is historically affected by landslides and flooding in the Northwest Zone (Figure 2), where there is a concentration of irregular housing and low-income, highly vulnerable population (Barbi, 2014).

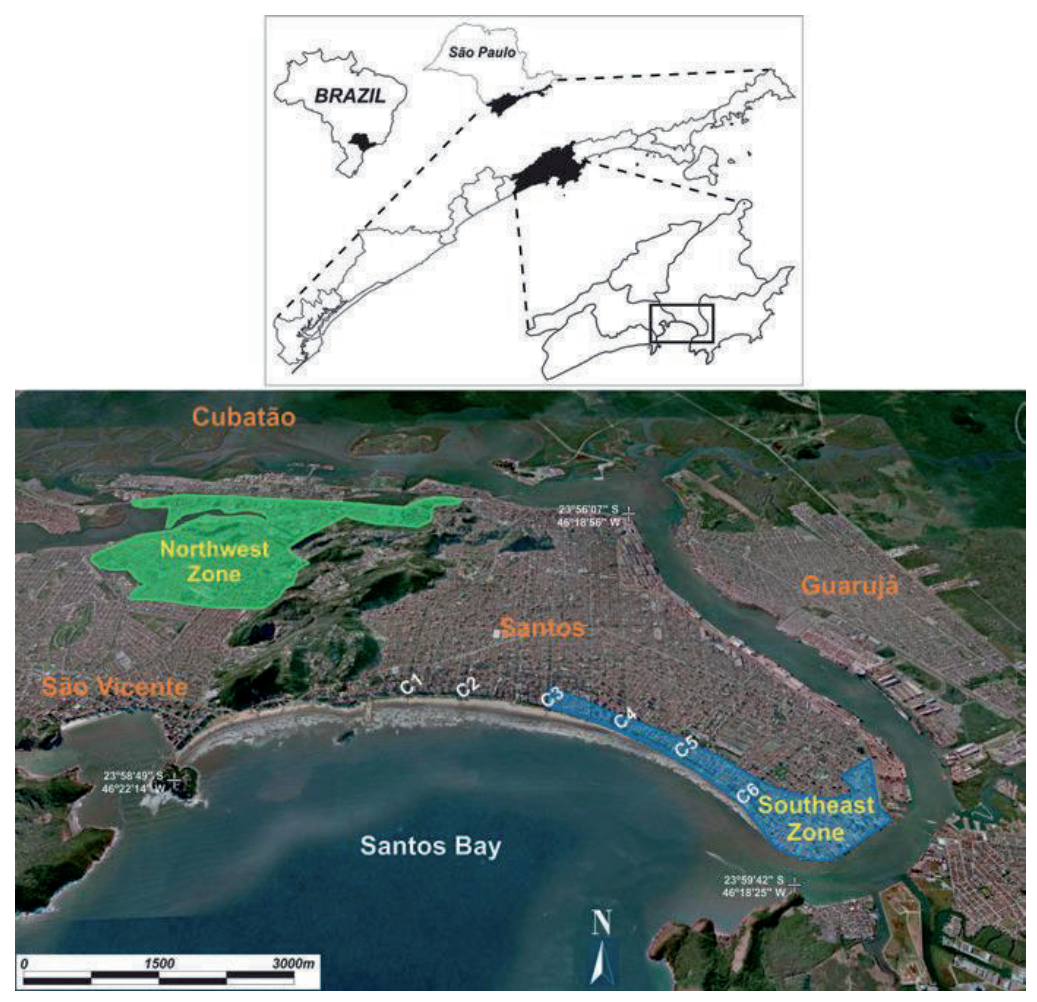


Figure 2. Map for the city of Santos.

Source: Harari et al. (2019).

Recently, the Southeast Zone of Santos has also been under increasing stress from an accelerating trend in beach erosion and flooding (Figure 3) linked to storm surges (Harari et al., 2019). It is a historically affluent region, especially the neighborhood of Ponta da Praia, which has touristic attractions such as the Municipal Aquarium and the beach segment with the best water quality in the city. It also has the worst perspectives for economic damage given sealevel rise projections (Marengo et al., 2017).

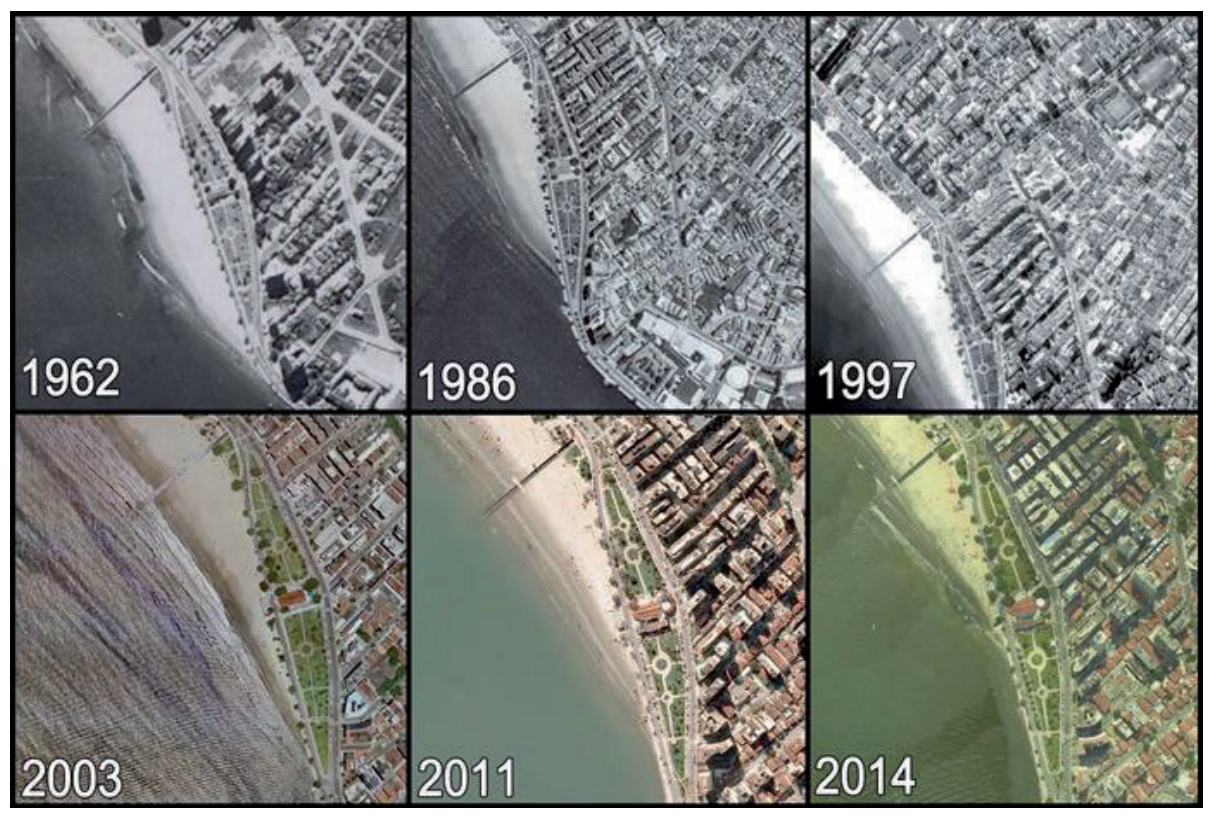

Figure 3. Beach erosion trend in Santos

Source: Freitas et al. (2019, p. 293).

The selection of Santos by the METROPOLE Project was a landmark for climate governance in the city. The municipal Committee for Climate Change was established two months after the release of the climate scenarios, in 2015. In 2016 there was the elaboration of the Municipal Climate Change Plan for Santos, followed by adaptation measures in the neighborhood of Ponta da Praia in 2017, and the selection for an Adaptation Project led by the national government in 2018. Given the relevance of institutional action in this period, the analysis was undertaken for the interval between 09/2015 and 04/2018, through the daily print newspaper A Tribuna de Santos.

The typology from Table 1 was detailed to differentiate between national and international sources in the case of Santos, given its location in the Global South (Figure 4). The results show a predominance of national scientific sources, reflecting the high media profile of scientists associated with the METROPOLE Project and with universities and research institutes based in the State of São Paulo, which are also the most internationalized in the country. On the other hand, there is lack of insertion of local residents, who are quoted only 4 times, mostly in moments of tragedy, such as loss of houses and life. Beyond the traditional reliance of the media on official sources, one factor that can be contributing to this dynamic is the absence of 
representative neighborhood associations in Santos, different from Selsey and Broward County (Paterson et al., 2017).

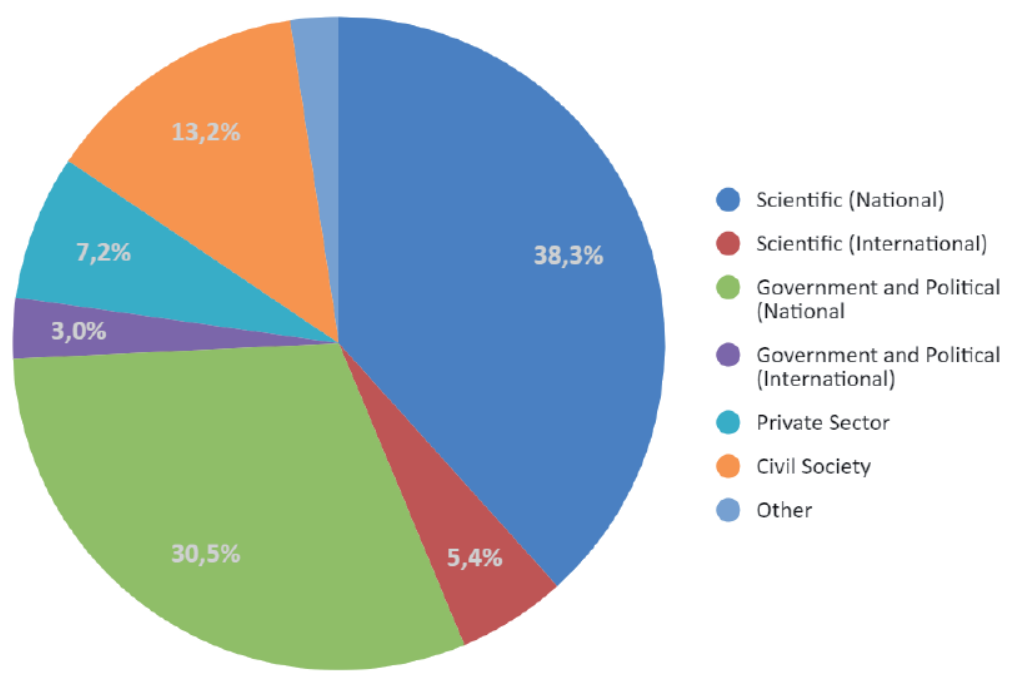

Figure 4. Sources in texts in A Tribuna de Santos ( $n=71$ texts, date range from 01/2015 to 03/2020) Source: elaborated by the author.

For Santos, 52 out of 71 texts contained at least one of the categories described in Table 3. Then, the main local issues outlined in Figure 5 explain 73\% (52 out of 71) of the sample obtained for climate change coverage in A Tribuna de Santos. Among them, 'Scientific projections' and 'Erosion and storm surges' are the most prominent, the first motivated by the release of the METROPOLE Project results and studies by State universities. The second is related to flooding and beach erosion in Ponta da Praia, a problem that at the end of the period also begins to be covered for other cities in the region, which are increasingly mentioned. Also very important is the discussion of the responsibilities of the Port regarding the erosion process, due to possible effects of the dredging expansion over the shoreline. An alternative focus identified regards future impacts of climate change in the Port.

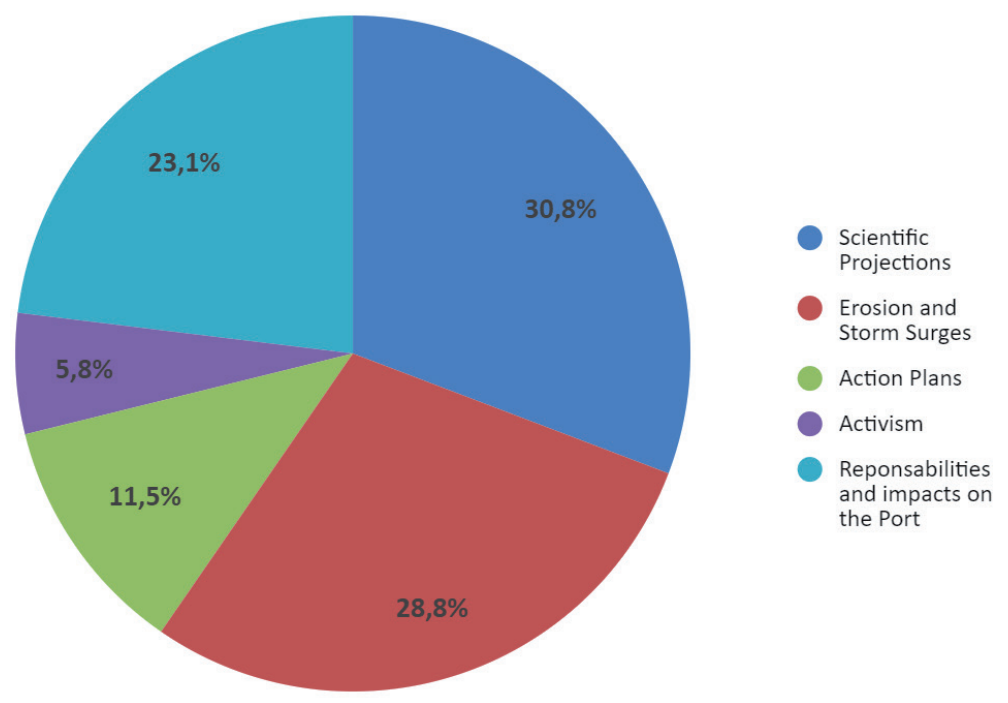


Figure 5. Texts with main local issues identified in A Tribuna de Santos ( $n=52$ texts, date range from $01 / 2015$ to $03 / 2020$ )

Source: elaborated by the author.

In Figure 6 the dynamic of mobilization is confirmed, showing that damage to beaches in the region surpass mentions to either the Port or the Northwest Zone neighborhoods, although the most precarious socio-environmental conditions are seen in the latter.

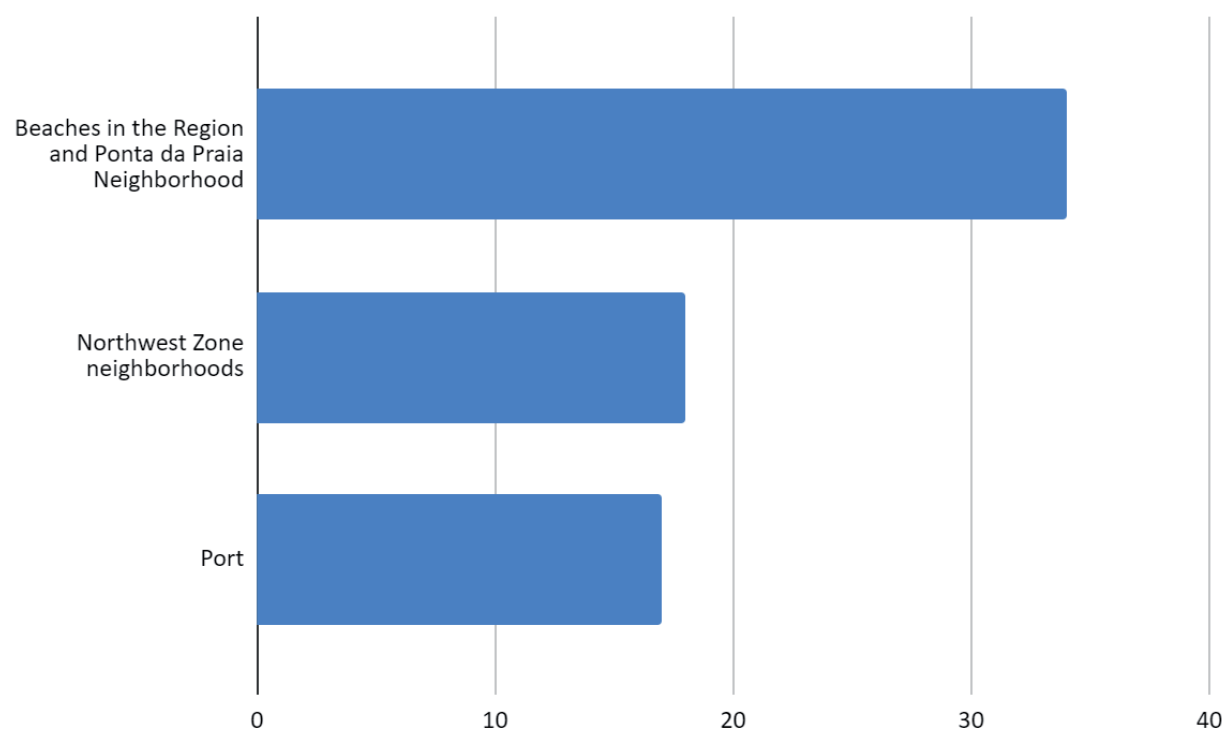

Figure 6. Mentions to affected parts of the city in texts in A Tribuna de Santos ( $\mathrm{n}=\mathbf{7 1}$ texts, date range from $01 / 2015$ to $03 / 2020$ )

Source: elaborated by the author.

In the case of Santos, there wasn't significant mention to the discussion about climate change denialism. However, there is relativization of the urgency of climate action, an expression of climate policy obstruction (Almiron et al., 2020). An interesting quote from the Logistics Director at the Port of Santos can be outlined:

Of course we have to analyze issues such as sea level rise. But in Brazil, ports still need so much investment, so much infrastructure. In Santos, we are still debating a new highway access to the Port, a demand from the last decade. Facing this urgency, we can even understand why we haven't debated this point, a demand that doesn't have such immediate effects." (Figueiredo, 2016, p. C-3)

\subsection{Broward County (USA)}

Broward County is located in the State of Florida and comprises the cities of Fort Lauderdale, Dania Beach, and Hollywood. An administrative level between the municipal and state levels, the county faces increasing risks of hurricanes and king tides, beyond the threat of saltwater infiltration in wellfields that provide drinkable water to the population (Vella et al., 2016). Environmental risks also include damages to the Everglades Port and ecosystem, beyond bleaching of the endemic coral reefs. The analyzed vehicle is the daily newspaper The Sun Sentinel, which is based in Broward and covers the region of South Florida. 
Since 2009, the county is involved in the Southeast Florida Compact for Climate Change (SFCCC), an informal organization between the counties of Monroe, Miami-Dade, Broward, and Palm Beach, intended to baseline the climate science for the region, lobby higher instances for funding and propose climate plans and adaptation options (Paterson et al., 2017). As a result, a Regional Climate Action Plan was adopted by all counties in 2012.

However, there has been controversy over the role of the State administration, deeply affecting the local climate change discussion. This article delimits this moment of political effervescence, between May of 2014 and January of 2016, between controversial declarations and actions by Governor Rick Scott, who was reported to have banned the term 'climate change' from official communications in May of 2015 (Paterson et al., 2017).

Starting with the source analysis, there is high concentration in the Governmental/Political quadrant (Figure 7), due to the high presence of SFCCC scientists in decision-making positions within the local governments. Nevertheless, there is also an important presence of scientists based in the Florida Atlantic University and the University of Miami, among others. Prominent Civil Society sources are dispersed between local residents, religious sources, NGOs such as the Nature Conservancy and local activists.

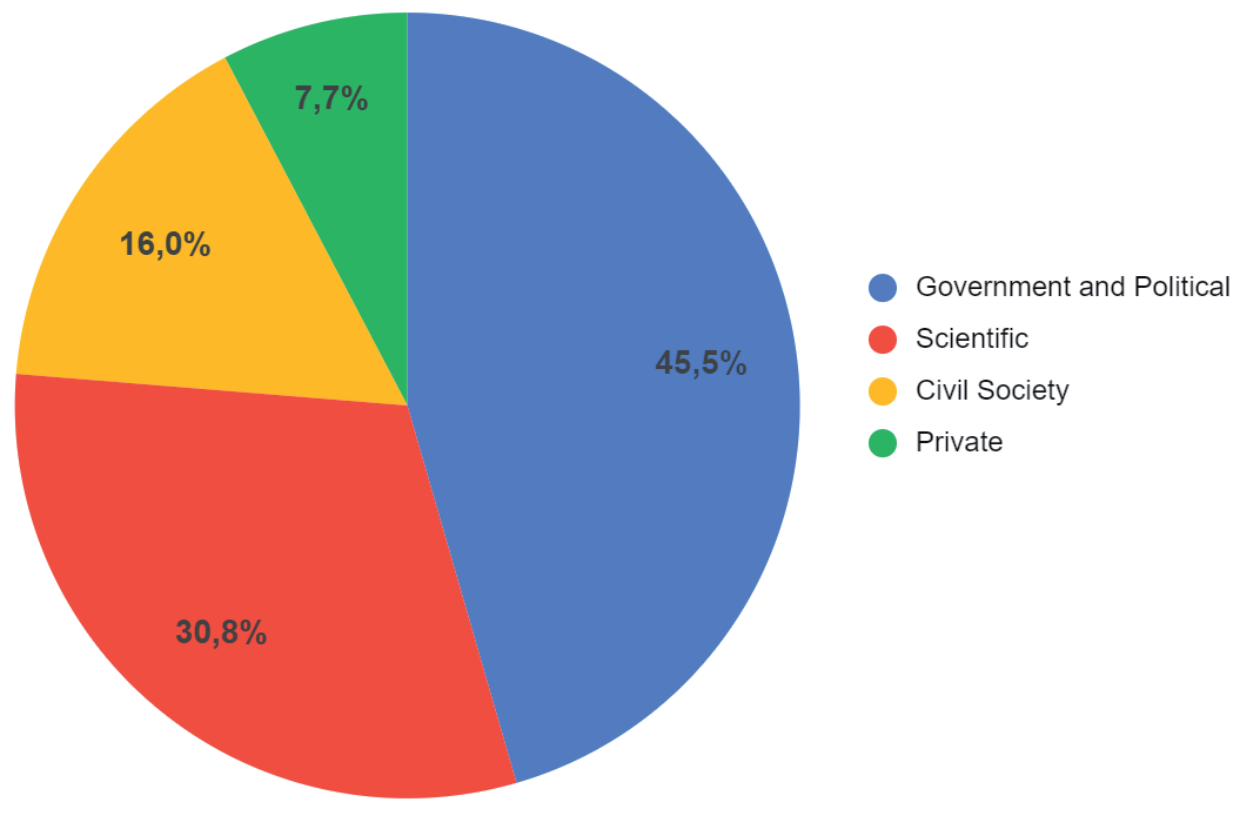

Figure 7. Sources in texts in The Sun Sentinel ( $n=145$ texts, date range from 05/2014 to 01/2016) Source: elaborated by the author.

Similar to Santos, affluent neighborhoods at risk from flooding and public goods such as beaches are the main focus, followed by concerns over coral bleaching (Figure 8). In contrast, there isn't a specific neighborhood that condenses the attention, given that the problem in Broward is more widespread, with the periodical experience of king tides and hurricanes.

The issues outlined in Figure 9 explain 67,59\% (98 out of 145) of the sample. The analysis renders interesting conclusions as denialism and elections are the most salient issues, showing how politicized the discussion is and how denial frames are prominent even in cities where 
dramatic effects are being felt and institutional action is being taken. Local activism, scientific projections, and action plans, taken together, constitute $17 \%$ of the identified issues, while 'Denialism' and 'Elections' comprise 31,5\% and 19,6\%, respectively.

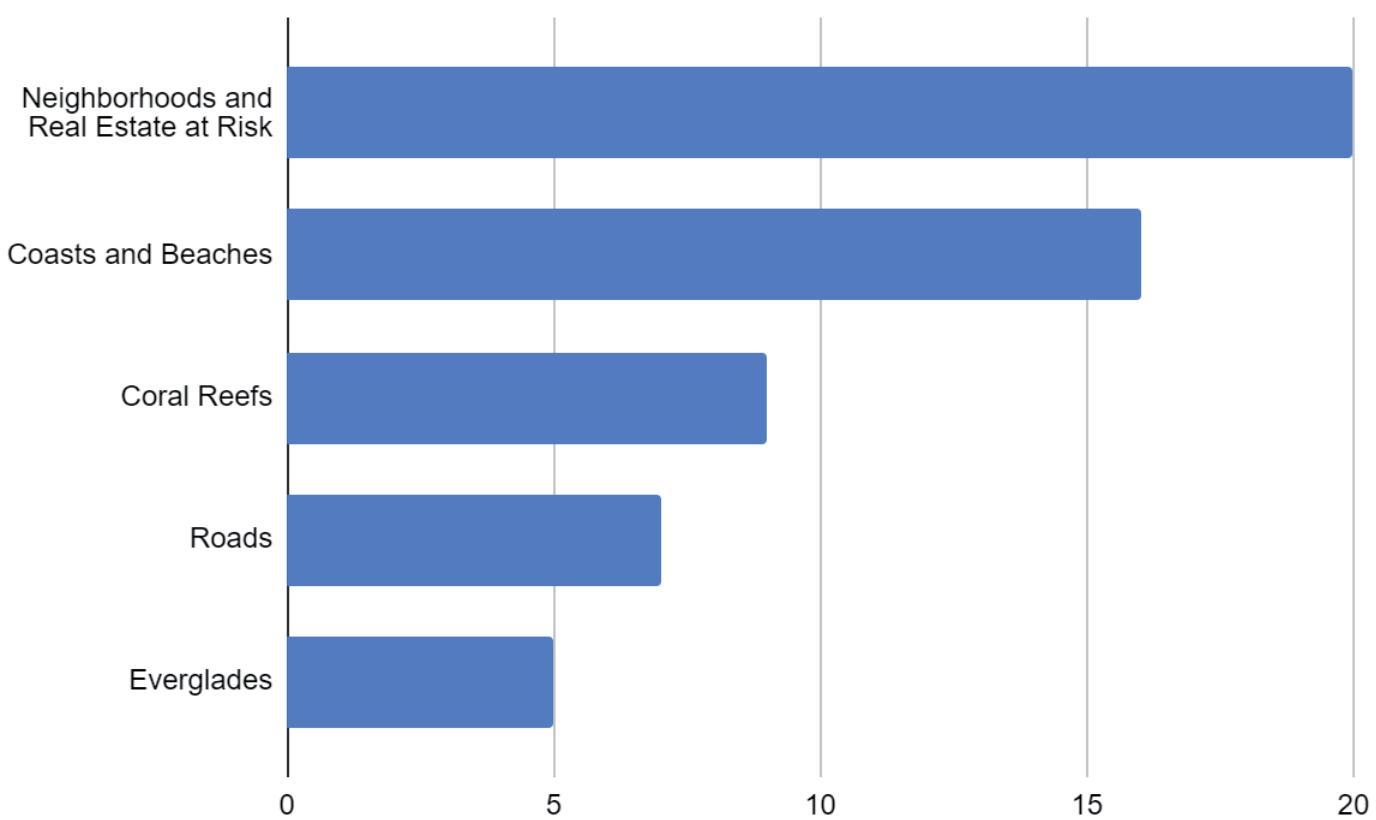

Figure 8. Mentions to affected parts of the city in texts in the 'Sun Sentinel' ( $n=145$ texts, date range from $01 / 2015$ to $03 / 2020$ )

Source: elaborated by the author.

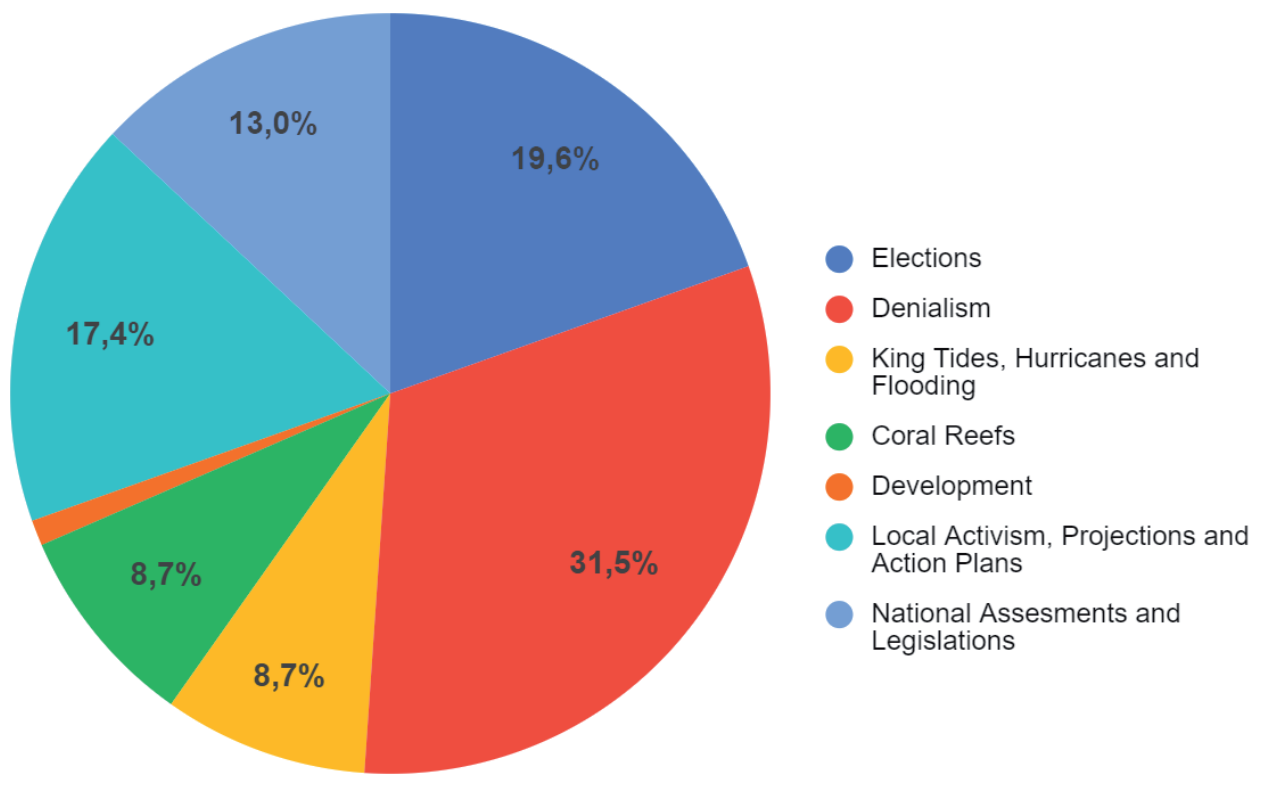

Figure 9. Texts with main local issues identified in The Sun Sentinel ( $n=98$ texts, date range from 05/2014 to 01/2016)

Source: elaborated by the author. 
Broward County was also the only case with a significant presence of denialist sources, in 27 out of 145 texts (18\%). Among these, 77\% are explained by the issues outlined in Figure 10, with predominance of the issues of elections and denialism.

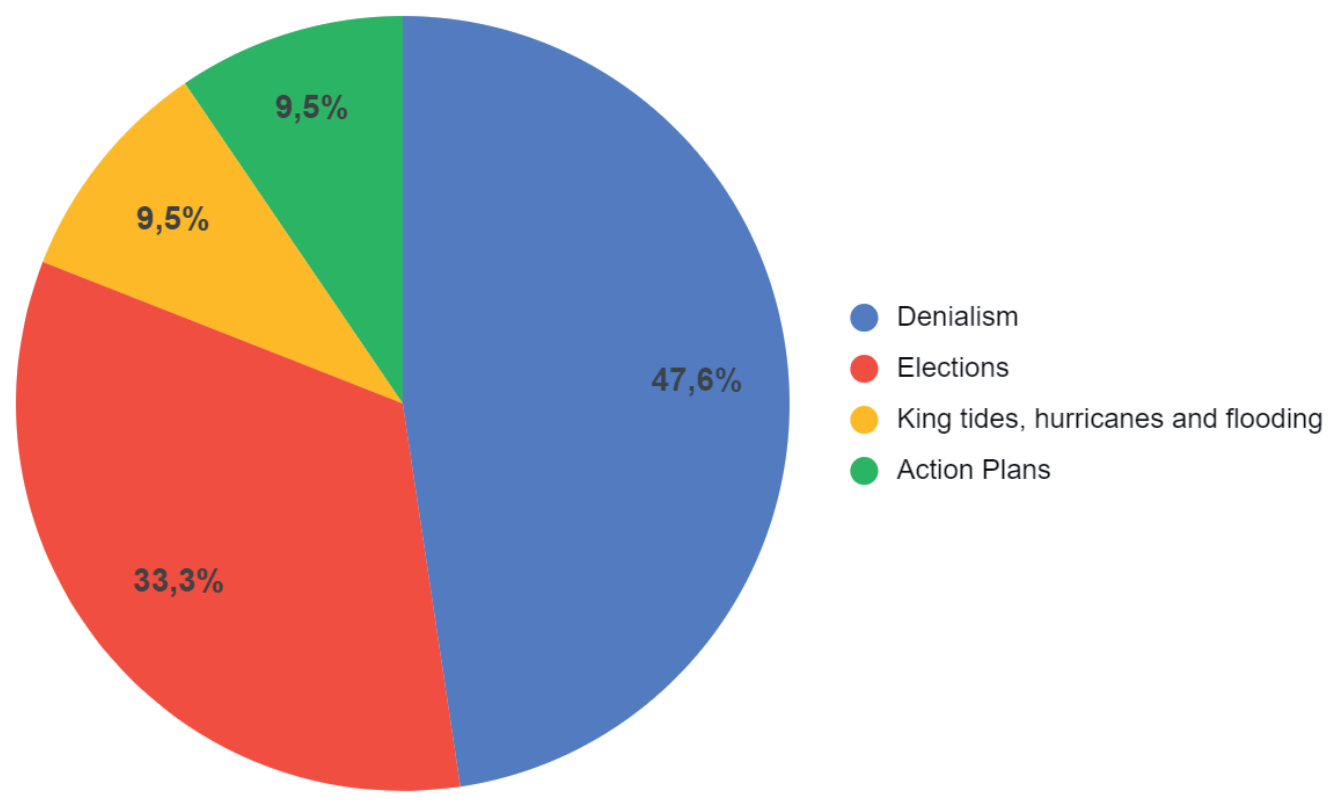

Figure 10. Main local issues in texts with climate-denialist sources in the Sun Sentinel ( $n=27$ texts, date range from 05/2014 to 01/2016)

Source: elaborated by the author.

Recurring climate-denialist sources are Governor Rick Scott, Florida Senator Marco Rubio, Representative Joe Gibbons, the Boca Raton Republican Club, the South Florida Tea Party, the think tank Center for Industrial Progress and the hunting association United Waterfowlers Florida. Also, there is the presence of multiple local residents who express themselves through letters to the editor, which constitute $22 \%$ (6 out of 27 ) of texts with denialist sources.

\subsection{Selsey (UK)}

Lastly, the town of Selsey is located in the Manhood Peninsula, within the Chichester District and West Sussex County. Here, there is a substantial administrative difference with the other cases, since in England local governments enjoy less autonomy than their counterparts in Brazil and the United States (Bulkeley \& Kern, 2006). However, after the Climate Change Act (2008) and the devolution of Water Management responsibilities, many of the measures related to climate change in coastal cities have been absorbed by local administrations (Paterson et al., 2017).

Selsey has been experimenting with coastal defenses since the 1950s, when the installation of sea barriers stopped one of the quickest processes of beach erosion around England. More recently, a coastal realignment experiment was carried out in the 2010s under the Medmerry Scheme. Part of the sea barriers was demolished to redirect wave energy into natural areas, creating inter-tidal habitat and avoiding damages to the built environment (Environment Agency, 2016). However, large areas of the Manhood Peninsula are projected to be flooded by 
2050 and pressure for real estate development presents increasing risks to coastal communities and ecosystems, especially the Chichester Harbour, an official Area of Outstanding Natural Beauty (Marengo et al., 2017).

In recent years, the Chichester District has been immersed in political disputes regarding climate change. There is a dual process as, on one hand, activists within the Extinction Rebellion have pressed for declarations of Climate Emergency in districts throughout the United Kingdom, and on the other hand, real estate developers and the central government have been pressing for development and housing initiatives in the region of West Sussex, which has about 142.000 hectares of protected green areas (West Sussex County Council, 2017). The last process has intensified with Brexit, as the UK is not obliged anymore to comply with EU environmental rules.

With that in mind, the analyzed vehicle was the weekly newspaper The Chichester Observer and the selected interval was $10 / 2015$ to $07 / 2021$, starting with the release of projections by the METROPOLE Project. By the end of 2018 the coverage intensified with the declaration of Climate Emergency by Chichester District, developments on West Sussex Climate Strategy and the approval of a number of controversial real estate development projects near valued natural Reserves such as South Downs National Park (SD).

Regarding source analysis (Figure 12), the difference in relation to Broward and Santos is visible, as civil society sources are the second most cited and there is only marginal mention to scientific sources. That can be explained by the lack of prestigious and internationalized universities in the Chichester District and the relevance of natural reserves in West Sussex, favoring the protagonism of activist environmentalist sources such as the Manhood Peninsula Action Group, the Save our South Coast Alliance, and the local chapters of the Extinction Rebellion, among others. There is also intense involvement of different levels of local government and green MPs, who stress the need to declare a climate emergency in response to the popular pressure. 


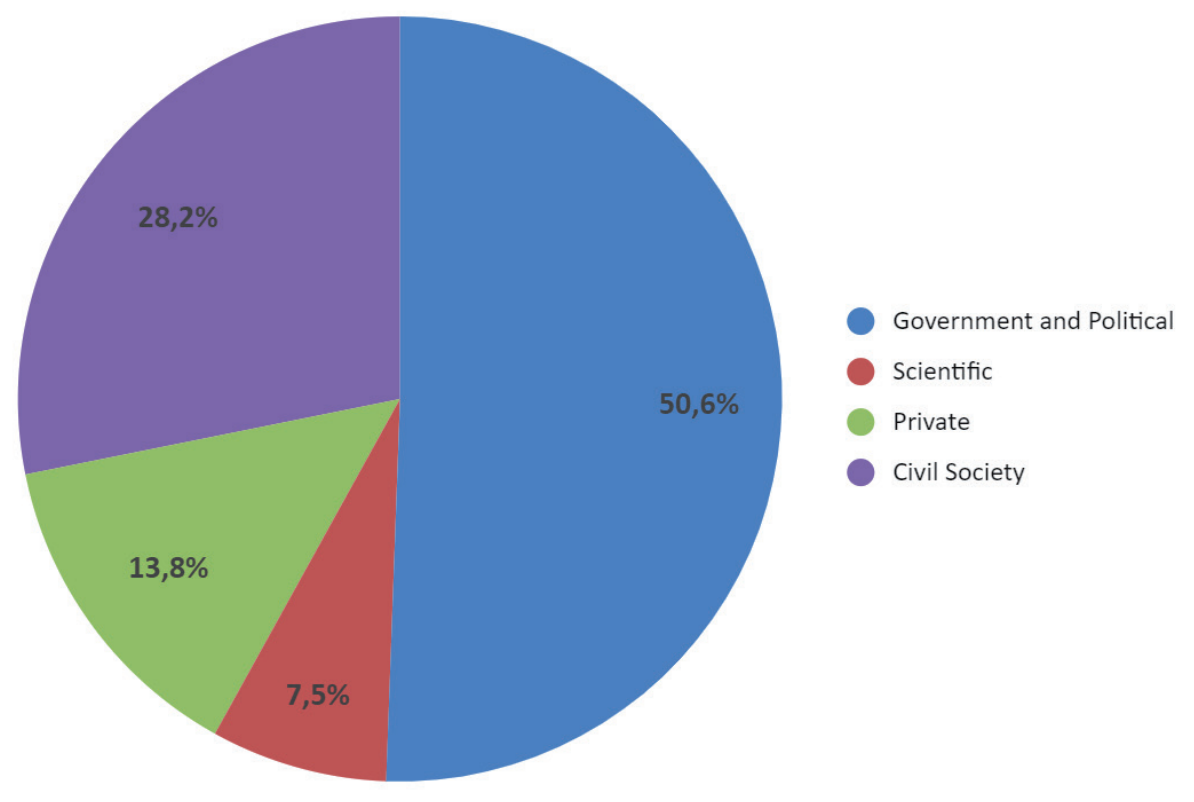

Figure 12. Sources in texts in the Chichester Observer $(n=122$ texts, date range from 10/2015 to 07/2021)

Source: elaborated by the author.

As can be deduced from the source analysis, the coverage stresses preservation of natural reserve areas, such as the Parks and Harbour (Figure 13).

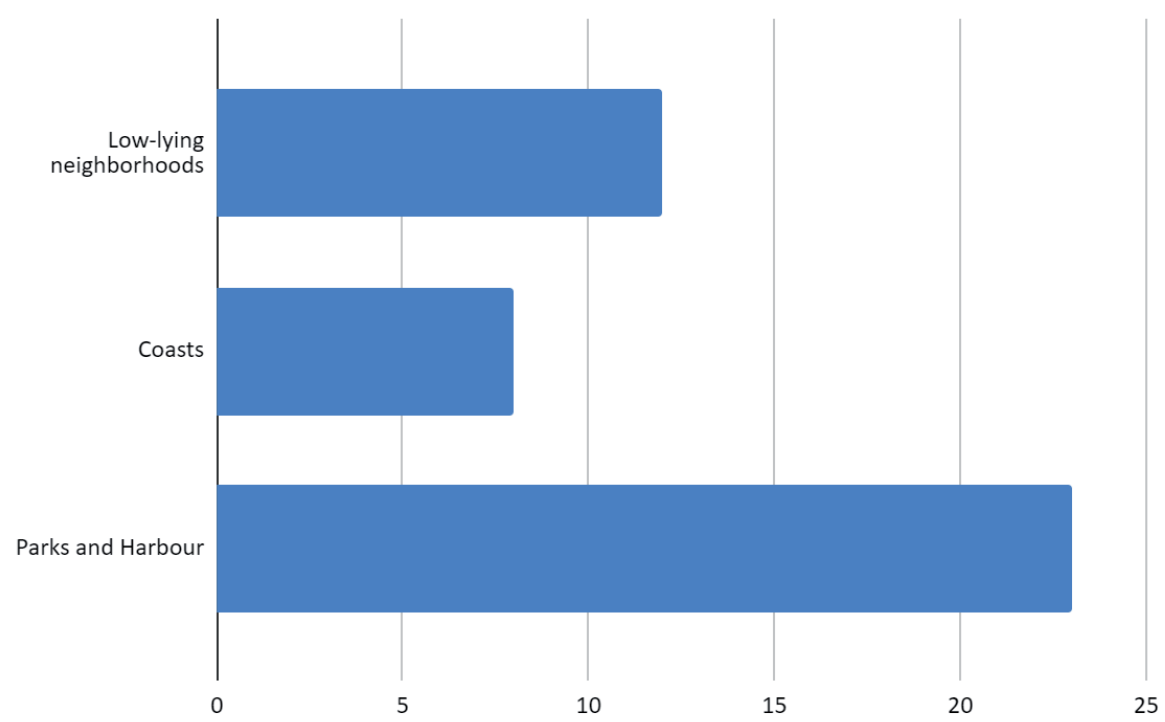

Figure 13. Impacted parts of the District in texts in the Chichester Observer $(n=122$ texts, date range from $10 / 2015$ to $07 / 2021$ )

Source: elaborated by the author.

Lastly, the main local issues in Figure 14 explain $63,1 \%$ (77 out of 122) of the sample and reveal three predominant foci: the pressure for declaration of a Climate Emergency; the institutionalized discussion of the Chichester District Action Plan, and controversies over real 
estate and road development, with the opposition of local activists and administrators to measures completed between District and Central Government.

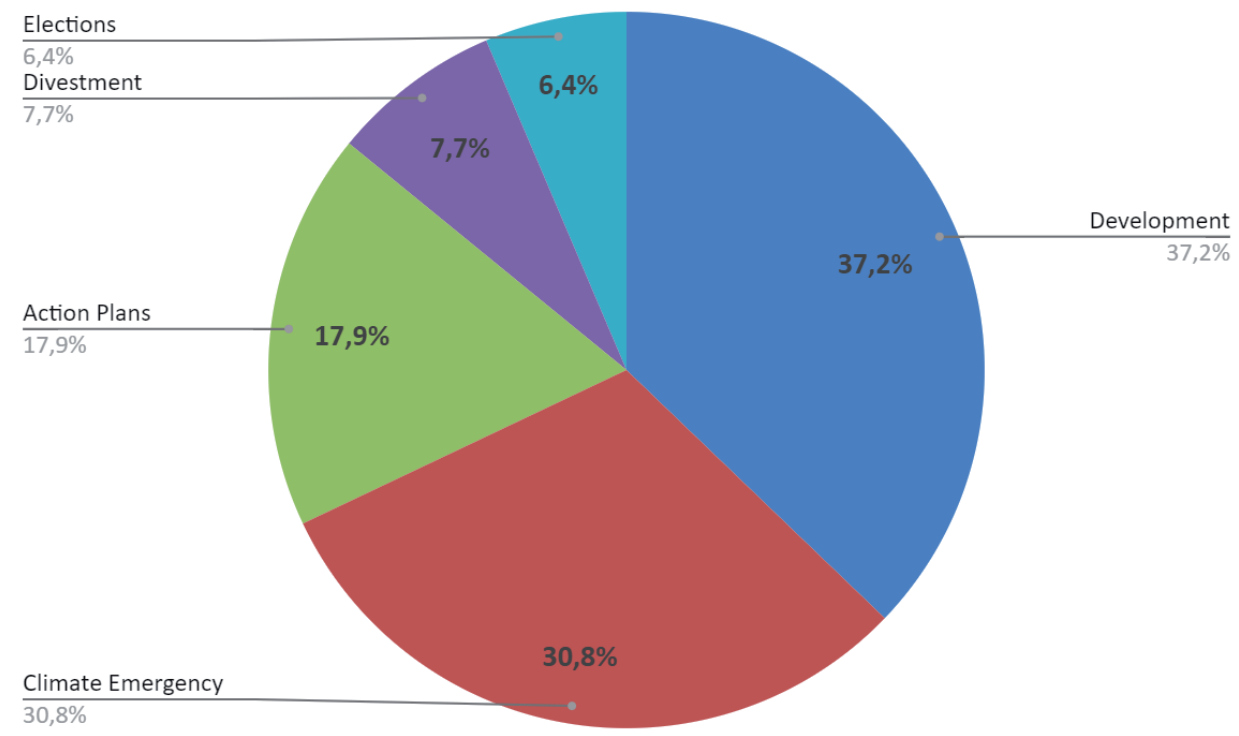

Figure 14. Texts with main local issues identified in The Chichester Observer ( $n=77$ texts, date range from $10 / 2015$ to $07 / 2021$ )

Source: elaborated by the author.

Some of the development initiatives that caused significant media attention are the proposed and rejected development of a link road to the A27 highway, close to preserved areas in SD, and tensions over the Review of the Chichester Local Plan. The latter reviewed the 2015 Local Plan and was last updated in June of 2021. During its elaboration process, environmental organizations raised concerns about regulation of real estate development, transport, and wastewater treatment, due to the increase in housing targets for the region imposed by the national government. Chichester District Council is currently questioning the figures proposed, arguing it is not a feasible number due to the environmental specificity of the region (Chichester District Council, 2021).

There is no significant presence of climate change denialism in the coverage, although private developments and Cabinet members are occasionally resistant to acknowledging implications of climate change when it comes to the questioning of oil and real estate initiatives, which can be observed in texts motivated by issues such as 'Development' and 'Divestment'. Therefore, there are expressions of obstruction to climate action.

\section{DISCUSSIONS AND CONCLUSIONS}

In all cases, the coverage is focused on specific symbols, a form of cognitively condensing emerging climate impacts. In Santos, it happens through the predominance in the coverage of impacts to beaches and to the neighborhood of Ponta da Praia. The Southeast Zone is seen as the frontier of climate impacts, amplifying the social risk perception. Although the Northwest 
Zone is in a more precarious situation, that is not as novel ${ }^{8}$ as the flooding in Ponta da Praia and implies less economic damage. Due to exclusion of local residents and the little mention to the Northwest Zone, it is possible to say that there is not only a novelty value, but also inequality of access at work in the coverage of $A$ Tribuna de Santos, reflecting the accentuated social inequality in the city.

Coasts, beaches, and valuable real estate on the shoreline are also predominant in the coverage in Broward County, although it is not so condensed around a specific symbol as in Santos. That can be explained due to the more widespread occasional flooding of various neighborhoods in Broward.

For Selsey, the most mentioned symbols are the natural reserves in the region, under constant threat of further real estate development.

Recovering the first hypothesis, it can be confirmed that in every region there is an attachment of the scientific discussion with local symbols and public goods. The latter are especially important in the case of Selsey, where environmentalist groups have higher relevance in the coverage, fostering a defense of local ecosystems and identity and denouncing plans for development in protected areas, a controversy that is hardly present in the other locations.

Although beaches and coasts also condense attention in Santos and Broward, the highly urbanized geographical profile and the strong presence of internationalized scientists also strengthen another aspect of the discussion, regarding the local economic burden resulting from climate change. The projections of climate scenarios usually stress benefit-cost ratios, which are dire for the affluent neighborhoods near the shorelines.

A point that is not in the scope of this short article, the conflicts between levels of government in Selsey also allow us to understand economic tensions underlying these case studies. The pressure for development of housing on land that is going to be flooded by 2050 goes in the opposite direction of climate adaptation, forwarding the question of whether climate governance experiments are being shaped to ensure protection of communities or to guarantee resiliency of high-value property (Bulkeley, 2021). This debate puts in evidence the complex interaction between risk definitions and incumbent relations of production (Beck, 2018; Bulkeley, 2001).

Regarding the second hypothesis, knowledge-related denialism was only found in Florida, with local media echoing the national political discussion. The denialist politicians and think tanks identified confirm the extensive literature that points to the alignment of the CCM with neoliberal or right-wing populist discourses (Brulle, 2013; Almiron et al., 2020). Despite the important local scientific and institutional developments, denialism continues to be the predominant theme in the coverage.

The few denialist references found in Santos and Selsey are policy-related and come from private organizations and government agencies related to development projects. In Santos, a main source of controversy is the expansion of dredging by the Port and its effects over the

${ }^{8}$ The described problems date from the 1980s (Barbi, 2014). 
beach landscape and the intensity of storm surges (Gutiérrez, 2021). After years of inaction, the Port Authority admitted to its contribution to such an intensification in 2017 (Ministério Público Federal, 2017). Furthermore, the measures of protection to the Port complex itself were delayed due to a 'short-term planning culture'. The justification provided by officials echoes the North/South debate in which it is argued that economic development in the Global South is a bigger priority than environmental preservation (Ferreira \& Tavolaro, 2008).

Some limitations of the article are also limitations of the object, as the analysis of media vehicles does not allow us to identify actors who act on the sidelines of public attention, as many lobbies for policy inaction now do (Hansen, 2010). However, the article is able to enlighten a contrast between the dynamics of inaction in the United States and in the other places studied. In the US, denialist sources seek attention of the media and bring the issue into their electoral discourses, deeply contaminating the debate and confirming the importance of elite cues (Brulle et al., 2012). In Brazil and England, obstructionist declarations seem 'accidental' and policy-related, on the part of companies and agencies focused on short-term economic interests. In all of these places, however, the root of such expressions is a conceptualized dichotomy between economy and environment.

Other limitations found were differences between the newspapers, as the The Chichester Observer differs in format and frequency from the others, factors that can lead to qualitative differences between them. The different time periods also constitute a limitation, since the greater presence of activist sources assessed in the case of Selsey is related to the momentum of climate protest and the declarations of Climate Emergency in European countries around 2019. The time periods analyzed for the other vehicles do not capture this moment, characterized by an eruption of climate activism and calls for action by the UN and the IPCC 1,5 ㄷ Report. By the end of 2019, this conjunction leads to the largest news peak since the one registered in 2009 due to the COP15 (Boykoff et al., 2021). Beyond these challenges, future research can also implement a qualitative discourse analysis as done in Mercado-Sáez, Suhuquilla-Verdet and Chávez (2019), also deepening the study about the major Actor/Sources.

Broader lines of research associated to the results here delivered are the empirical and theoretical assessment of the relations between risk definitions and production modes. How does this debate happen in cities with less visible impacts? Is the climate change discussion present, and is there denialist content in these cases? 


\section{NOTES}

This article elaborates the presentation given during the THINKClima Conference 'Lobbying for (in)action: Climate emergence, interest groups and denial', on May 27th of 2021. This work expands results from the master's thesis financed by the CAPES Agency (Financing Code: 0001) and presented by Gutiérrez (2021) for the city of Santos and is associated to the overarching project "The Challenge of Climate Change Governance in Brazil: a multilevel and multi actor approach (The case of the State of São Paulo)", funded by São Paulo Research Foundation (Process no 19/14867-2), and coordinated by Prof. Leila da Costa da Ferreira.

\section{References}

Akerlof, K. L., Rowan, K. E., La Porte, T., Batten, B. K., Ernst, H., \& Sklarew, D. M. (2016). Risky business: Engaging the public on sea level rise and inundation. Environmental Science and Policy, 66, 314323. https://doi.org/10.1016/j.envsci.2016.07.002

Almiron, N., Boykoff, M., Narberhaus, M., \& Heras, F. (2020). Dominant counter-frames in influential climate contrarian European think tanks. Climatic Change, 162(4), 2003-2020. https://doi.org/10.1007/s10584-020-02820-4

ANDI (2010). Mudanças climáticas na imprensa brasileira: Uma análise comparativa da cobertura feita por 50 jornais feita entre julho de 2005 e dezembro de 2008 (Coordinated by Veet Vivarta). Agência de Notícias dos Direitos da Infância (ANDI) \& British Embassy Brasília. https://andi.org.br/wp-content/uploads/2020/09/Mudanca-climatica-na-imprensa-brasilerira2005-2008.pdf https://bit.ly/3dON9gx

Andrade, T. H. N. (1994). Meio Ambiente e Imprensa: Estudo de caso da Eco-92. Unicamp.

Barbi, F. (2014). Mudanças climáticas e respostas políticas: os riscos na Baixada Santista. [Doctoral Thesis, State University of Campinas].

Bardin, L. (1977). Análise de Conteúdo. Edições 70.

Batty, S., Davoudi, S., \& Layard, A. (2008). Sustainable Development and Planning: An overview. In Planning for a Sustainable Future (pp. 7-19). Taylor \& Francis.

Beck, U. (2018). A Metamorfose do Mundo. Editora Zahar.

Boykoff, M. T., \& Boykoff, J. M. (2007). Climate change and journalistic norms: A case-study of US massmedia coverage. Geoforum, 38(6), 1190-1204. https://doi.org/10.1016/j.geoforum.2007.01.008

Boykoff, M. (2011). Who speaks for climate? Cambridge University Press. https://doi.org/10.1017/СBO9780511978586

Boykoff, M., Aoyagi, M., Ballantyne, A.G., Benham, A., Chandler, P., Daly, M., Doi, K., Fernández-Reyes, R., Hawley, E., Jiménez Gómez, I., Lyytimäki, J., McAllister, L., McNatt, M., Mervaala, E., Mocatta, G., Nacu-Schmidt, A., Oonk, D., Osborne-Gowey, J., Pearman, O., Petersen, L.K., Simonsen, A.H., and Ytterstad, A. (2021). World newspaper coverage of climate change or global warming, 2004-2021. Media and Climate Change Observatory Data Sets. Cooperative Institute for Research in Environmental Sciences, University of Colorado. https://doi.org/10.25810/4c3b-b819

Braasch, G. (2013). Climate change: Is seeing believing? Bulletin of the Atomic Scientists, 69(6), 33-41. https://doi.org/10.1177/0096340213508628

Broto, V. C., \& Bulkeley, H. (2013). A survey of urban climate change experiments in 100 cities. Global Environmental Change, 23(1), 92-102. https://doi.org/10.1016/j.gloenvcha.2012.07.005

Brulle, R. J. (2013). Institutionalizing delay: foundation funding and the creation of U.S. climate change 
counter-movement organizations. Climatic Change, 122(4), 681-694. https://doi.org/10.1007/s10584-013-1018-7

Brulle, R. J., Carmichael, J., \& Jenkins, J. C. (2012). Shifting public opinion on climate change: An empirical assessment of factors influencing concern over climate change in the U.S., 2002-2010. Climatic Change, 114(2), 169-188. https://doi.org/10.1007/s10584-012-0403-y

Bulkeley, H. (2001). Governing climate change: The politics of risk society? Transactions of the Institute of British Geographers, 26(4), 430-447. https://doi.org/10.1111/1475-5661.00033

Bulkeley, H. (2021). Climate changed urban futures: environmental politics in the anthropocene city. Environmental Politics, 30(1-2), 266-284. https://doi.org/10.1080/09644016.2021.1880713

Bulkeley, H., \& Kern, K. (2006). Local government and the governing of climate change in Germany and the UK. Urban Studies, 43(12), 2237-2259. https://doi.org/10.1080/00420980600936491

Chakrabarty, D. (2009). The climate of history: Four theses. Critical Inquiry, 35(14), $197-222$. https://doi.org/10.7203/KAM.14.15052

Chichester District Council. (2021). Chichester local plan review update: 22 June 2021. Chichester District Council. https://bit.ly/3yzBzzz

Darr, J. P., Hitt, M. P., \& Dunaway, J. L. (2018). Newspaper closures polarize voting behavior. Journal of Communication, 68(6), 1007-1028. https://doi.org/10.1093/joc/jqy051

Douglas, M., \& Wildavsky, A. (1983). Risk and culture. University of California Press.

Environment Agency. (2016). Medmerry Managed realignment - Monitoring update: Summer 2016. UK Government. Environment Agency. https://bit.ly/3IL9WYFhttp://www.cdas.info/PDF/Medmerry\%20monitoring\%202016\%20report \%20final.pdf

Ferreira, L. da C., \& Tavolaro, S. B. F. (2008). Environmental concerns in contemporary Brazil: An Insight into Some Theoretical and Societal Backgrounds (1970s-1990s). International Journal of Politics, Culture and Society, 19(3/4), 161-177. https://doi.org/10.1007/s10767-008-9021-0

Freitas, D. M., Carvalho D. A., Hosokawa, E. K. (2019) Adapting to a changing climate: An operational space for local adaptation committee in Santos coastal area. In Climate Change in Santos Brazil, Impacts and Adaptation Options. Cham: Springer Nature Switzerland (pp. 285-302).

Figueiredo, L. (2016, October 30). Porto deve se preparar para os impactos do avanço do mar. A Tribuna de Santos, C-3.

Gamson, W., Modigliani, A. (1989). Media discourse and public opinion on nuclear power. The American Journal of Sociology, 95(1), (1-37).

Gutiérrez, E. P. (2021). Governança das mudanças climáticas em Santos e sua cobertura na mídia impressa: Uma análise relacional entre 2015 e 2020. [Master's Dissertation, State University of Campinas].

Hall, S. (1973). The "structured communication" of events. In Obstacles to Communication Symposium. http://epapers.bham.ac.uk/2960/1/Hall_SOP05_1973.pdf

Hannigan, J. (2006). Environmental Sociology. Routledge. https://doi.org/10.4324/9780203001806

Hansen, A. (2010). Environment, Media and Communication. Routledge. https://doi.org/10.4324/9780203860014

Harari, J., Camargo, R. de, Souza, C. R. de G., \& Nunes, L. H. (2019). Projections and uncertainties of sea level trends in Baixada Santista. In Climate Change in Santos Brazil: Projections, Impacts and Adaptation Options (pp. 75-97). Springer Nature Switzerland.

Jasanoff, S. (2010). A new climate for society. Theory, Culture and Society, 27(2), 233-253. https://doi.org/10.1177/0263276409361497 
Kahan, D. (2010). Fixing the communications failure. Nature, 463(7279), $296-297$. https://doi.org/10.1038/463296a

Leiserowitz, A. A., Maibach, E., Rosenthal, S., Kotcher, J., Bergquist, P., Ballew, M., Goldberg, M., Gustafson, A., \& Wang, X. (2020). Climate Change in the American Mind: April 2020. Yale Program on Climate Change Communication. https://bit.ly/3ISGz78

Lorenzoni, I., Nicholson-Cole, S., \& Whitmarsh, L. (2007). Barriers perceived to engaging with climate change among the UK public and their policy implications. Global Environmental Change, 17(34), 445-459. https://doi.org/10.1016/j.gloenvcha.2007.01.004

Marengo, J., Muller-Karger, F., Pelling, M., Reynolds, C. J., Merrill, S. B., Nunes, L. H., Paterson, S., Gray, A. J., Lockman, J. T., Kartez, J., Moreira, F. A., Greco, R., Harari, J., Souza, C. R. G., Alves, L. M., Hosokawa, E. K., \& Tabuchi, E. K. (2017). An integrated framework to analyze local decision making and adaptation to sea level rise in coastal regions in Selsey (UK), Broward County (USA), and Santos (Brazil). American Journal of Climate Change, 06(02), 403-424. https://doi.org/10.4236/ajcc.2017.62021

Mason, L. (2016). A cross-cutting calm: How social sorting drives affective polarization. Public Opinion Quarterly, 80(Special issue 1), 351-377. https://doi.org/10.1093/poq/nfw001

McCright, A. M., \& Dunlap, R. E. (2010). Anti-reflexivity: The American conservative movement's success in undermining climate science and policy. Theory, Culture and Society, 27(2), 100-133. https://doi.org/10.1177/0263276409356001

Mercado-Sáez, M. T., Sahuquillo-Verdet, F. Y., Chávez, M. (2019). Social media framing in the journalistic coverage of oil survey permits in the Mediterranean. Communication \& Society, 32(4), 307-323. https://doi.org/10.15581/003.32.4.307-323

Ministério Público Federal (2017). Termo de acordo para homologação judicial nos autos da ação civil pública no 0004665-36.2015.403.6104 da 3a Vara Federal em Santos. Brazilian Government. https://bit.ly/3s2t3b2

Nisbet, M. C. (2010). Knowledge into action: Framing the debates over climate change and poverty. In J. A. Kuypers \& P. D'Angelo (Eds.), Doing News Framing Analysis Theoretical and Empirical Perspectives. Routledge.

O'Neill, S., \& Nicholson-Cole, S. (2009). "Fear won't do it": Promoting positive engagement with climate change through visual and iconic representations. Science Communication, 30(3), 355-379. https://doi.org/10.1177/1075547008329201

Paterson, S. K., Pelling, M., Nunes, L. H., de Araújo Moreira, F., Guida, K., \& Marengo, J. A. (2017). Size does matter: City scale and the asymmetries of climate change adaptation in three coastal towns. Geoforum, 81, 109-119. https://doi.org/10.1016/j.geoforum.2017.02.014

Pidgeon, N., Kasperson, R. E., \& Slovic, P. (2003). Conceptual foundations. In The social Amplification of Risk (pp. 11-12). Cambridge University Press. https://doi.org/10.1017/CBO9780511550461

Shwom, R. L., McCright, A. M., Brechin, S. R., Dunlap, R. E., Marquart-Pyatt, S. T., \& Hamilton, L. C. (2015). Public opinion on climate change. In R. E. Dunlap \& R. J. Brulle (Eds.), Climate Change and Society (pp. 269-299). Oxford University Press. https://doi.org/ 10.1093/acprof:oso/9780199356102.003.0009

Van Gorp, B. (2010). Strategies to take subjectivity out of framing analysis. In P. D'Angelo \& J. A. Kuypers (Eds.), Doing News Framing Analysis (pp. 84-110). Taylor \& Francis.

Vella, K., Butler, W. H., Sipe, N., Chapin, T., \& Murley, J. (2016). Voluntary collaboration for adaptive governance: The Southeast Florida regional climate change compact. Journal of Planning Education and Research, 36(3), 363-376. https://doi.org/10.1177/0739456X16659700

West Sussex County Council. (2019). About West Sussex. West Sussex County Council. https://bit.ly/3ESXQKK 


\section{About the author}

Eduardo Prado Gutiérrez studies social and interdisciplinary issues related to climate change, and has received a Master's Degree in Sociology from the State University of Campinas (Brazil) for the completion of his Dissertation "Governance of Climate Change Governance in SantosSP and coverage in the local print media: a relational analysis between 2015 and 2020", supervised by Prof. Dr. Leila da Costa Ferreira. For completion of the master's degree, he has received support from the Brazilian agency CAPES between March 2019 and March 2021 (Code 001). 